\title{
Formation of regional conditions for innovative development of Russian small businesses
}

\author{
V.S. Parshina ${ }^{1, *}$, T.I. Satsuk ${ }^{2}$, and T.I. Vladimirova ${ }^{3}$ \\ ${ }^{1}$ Ural State University of Railway Transport, Yekaterinburg, Russia \\ ${ }^{2}$ St. Petersburg State University of Railway Transport, Saint-Petersburg, Russia \\ ${ }^{3}$ Siberian State University of Railway Transport, Novosibirsk, Russia
}

\begin{abstract}
The sustainable development of the economy depends largely on the pace of innovation introduction, which is associated with the patent activity. The dependence of the economy of a country (region) on innovation and patent activity is well shown by specialists. The organization of patenting in small and medium-sized enterprises (SMEs) is insufficiently researched. The article presents the positive dynamics of the main economic indicators of China and the factors, ensuring their implementation. To identify the available reserves in this sector of the economy of our country, the interaction of small innovative enterprises (SIE) and patent organizations of the Russian Federation has been considered. In order to determine the significant characteristics and criteria, by which the SIE chooses a patent office, a questionnaire was conducted, the results of which allow to draw a conclusion regarding the ways to intensify patent activity. The proposed version of the methodology for assessing the effectiveness of patents at the initial stage of their formation will create a basis for the interaction of the state with the SIE and the SIE with patent offices at the regional level. Further research will be dedicated to specifying the elements of assessing the quality of patents, developing a methodology for assessing the quality of work of patent offices, formalizing the assessment procedure, and testing the developed methodology.
\end{abstract}

\section{Introduction}

"The importance of the development of scientific and technological potential, which many countries already possess is critically increasing..." (from the speech of the President of the Russian Federation V.V. Putin on 30/04/2020). The indicated direction actualizes the research of the factors of innovative development, including in the field of small business, due to the effective interaction of SIE, patent offices and the state. The features of joint activity of a network of organizations, involved in the patenting process, have been considered. This basic premise applies to SIEs and their cooperating patent offices. For small businesses, it is possible to provide innovation activity on the basis of successful contacts with independent patent offices and government organizations.

\footnotetext{
*Corresponding author: vparshina@usurt.ru
} 


\section{Materials and methods.}

The study of literary sources allowed to reveal the great interest of foreign authors (including F.M. Scherer and D. Ross [1], D. Shmukler [2], Z. Griliches [3], B.H. Hall [4] and others) to study the dependence of the economic indicators of a country, region and organization on the intensity of innovation and patent activities.

As the experience of developed countries shows, in recent years, the leading role in the formation of GDP has been actively occupied by small businesses and, above all, those, engaged in innovation activity. The authors pay attention to the characteristic of each country in the development of this field of activity [5-8]. To implement innovations in our country, such organizational structures use the services of patent offices. Under the current conditions, the share of small innovative enterprises in the Russian Federation is only $4.5 \%$, and the share of innovative goods, works, and services they produce in the total volume of goods shipped, works and services performed on their own is $1.6 \%$, which indicates large reserves of development of this sector of the economy in our country.

China was chosen as the object of comparison, which clearly demonstrates the possibility of developing small and medium-sized enterprises (SMEs) on the basis of innovations, largely due to patenting. The analysis of GDP from 2008 (the year of the world crisis) to the present time is carried out. The main argument, illustrating China's achievements, is the dynamics of GDP (Table 1).

Table 1. China's GDP dynamics $[9,10]$

\begin{tabular}{|l|c|c|c|c|c|c|}
\hline Indicator & 2008 & 2012 & 2017 & 2018 & 2019 & $2019 / 2008, \%$ \\
\hline GDP, USD bln. USA & 4,604 & 8,570 & 12,062 & 13,407 & 14,216 & 308 \\
\hline GDP per capita, USD USA & 3,425 & 6,232 & 8,697 & 9,612 & 10,093 & 295 \\
\hline Population, million people & $1,323.2$ & $1,351.8$ & $1,386.9$ & $1,394.1$ & $1,408.5$ & 106 \\
\hline
\end{tabular}

The high economic results, recorded in China, are largely due to the innovation activity of SMEs. Focusing on small business in this article, we will illustrate the dynamics of the development of this field (Table 2).

Table 2. Main indicators of SMEs in China [11]

\begin{tabular}{|l|c|c|c|c|c|c|}
\hline Indicator & 2008 & 2012 & 2017 & 2018 & 2019 & $\begin{array}{c}2019 / 2008, \\
\%\end{array}$ \\
\hline Number of SMEs, thousand units & 4,655 & 6,500 & 10,163 & 11,630 & 13,130 & 281 \\
\hline $\begin{array}{l}\text { Share of SMEs in the country's } \\
\text { GDP, } \%\end{array}$ & - & 50.5 & 79.3 & 85.4 & - & - \\
\hline
\end{tabular}

During the period under consideration, there was an almost three-fold increase in the number of SMEs in China, which, according to statistics, own $65 \%$ of patents. When analyzing the sectoral structure of small business in China, it should be noted, that $45 \%$ of the total number of such enterprises is in the manufacturing industry, which forms the activity in terms of innovative transformations of this group of enterprises. Next, let us compare the above dynamic results of economic development, the significant role of small business in it, with the state of innovation activity, largely due to active patenting (Table 3 ). It should be noted, that due to frequent changes in the methodology for calculating the number of patents in China, it was difficult to provide figures, comparable over the years. 
Table 3.The main results of the patent activity of China $[12,13]$

\begin{tabular}{|l|c|c|c|c|c|}
\hline Indicators & 2008 & 2012 & 2017 & 2018 & 2019 \\
\hline Number of patent applications filed, thous. pcs. & 203.5 & 526.4 & $1,476.0$ & $1,381.6$ & $1,542.0$ \\
\hline \% of the total in the world & 15.1 & 22.4 & 46.6 & 41.8 & 48.0 \\
\hline $\begin{array}{l}\text { Number of applications filed per 10 thousand } \\
\text { people, pcs. }\end{array}$ & 1.5 & 3,9 & 10.6 & 9.9 & 10.9 \\
\hline Number of issued patents, thousand pcs. & 48.8 & 220.0 & 425.1 & 432.2 & 453.0 \\
\hline $\begin{array}{l}\text { Number of issued patents per 10 thousand people, } \\
\text { pcs. }\end{array}$ & 0.4 & 1.6 & 3.1 & 3.1 & 3.2 \\
\hline
\end{tabular}

During the analyzed period, the total number of patent applications filed increased 7.6 times and reached about $50 \%$ of their worldwide number. The number of issued patents increased more than 9 times (from 48.8 to 453.0). This figure is calculated without taking into account shift due to different filing and obtaining periods for patents. A confirmation of the possibility of such data presentation is a significant reduction in the application lead time in recent years.

For comparison, we present the general indicators of patent activity in the Russian Federation (Table 4).

Next, we will focus on identifying the reserves for increasing the efficiency of patenting in small business. As an important factor of the successful activity of organizations, the authors have recently begun to highlight the issues of effective interaction of various subjects of activity in order to maximize serving the interests of the parties $[17,18]$.

In recent years, the authors have paid attention to the research of the conditions for increasing the efficiency of activity of subjects through the interaction of parties concerned [19]

Table 4. Indicators of patent activity of the Russian Federation [14 -16]

\begin{tabular}{|l|c|c|c|c|c|}
\hline Indicators & 2008 & 2012 & 2017 & 2018 & 2019 \\
\hline Number of applications filed, thousand pcs. & 41.8 & 44.2 & 36.5 & 37.9 & 35.5 \\
\hline $\begin{array}{l}\text { Number of applications filed per 10 thousand } \\
\text { people of the country }\end{array}$ & 2.9 & 3.1 & 2.5 & 2.5 & 2.4 \\
\hline Number of issued patents, thousand pcs. & 28.8 & 32.9 & 34.3 & 35.8 & 34.0 \\
\hline $\begin{array}{l}\text { Number of issued patents per 10 thousand people } \\
\text { of the country }\end{array}$ & 2.9 & 2.3 & 2.3 & 2.5 & 2.6 \\
\hline \% of obtained from filed (with shift) & 0.79 & 0.74 & 0.92 & 0.94 & - \\
\hline Number of valid patents. thousand pcs. & 147.1 & 181.5 & 244.3 & 256.4 & 263.7 \\
\hline
\end{tabular}

in the process of joint actions, which leads to a decrease in transaction costs; there are articles on organizing networks of SIEs to accelerate innovations [20] or the development and marketing of patent information services for SMEs [21]. At the same time, the literary sources did not reveal the results of research on the interaction of SIEs with patent offices and models for its improvement.

\section{Results and discussions.}

To date, a list of organizations, carrying out patent activity, has been formed:

- $\quad$ independent organizations, providing patent services:

a) patent offices;

b) patent specialists, engaged in private practice, including patent attorneys; 
c) other organizations, providing patent services (law firms, chamber of commerce and industry);

- patent departments of organizations (research institutes, universities or other institutions), in which they carry out patent work;

- $\quad$ organizations, that register patent documents.

A special place in modern conditions is occupied by regional patent offices - consulting firms, providing services to small businesses in the field of patenting. The essence of the scientific problem of increasing the efficiency of managing the interaction of partners in patent activity is the need to form a new methodological approach, that allows to propose an organizational mechanism for patent activity, that is adequate to the specifics and needs of the economic development of the region.

To identify the existing reserves of innovations in the region, let us consider the interaction of SIE and independent patent organizations. In order to determine the significant characteristics and criteria, by which SIEs choose a patent office (or refuse their services), a questionnaire was developed, including 20 questions. The target audience of the questionnaire was the heads of 123 small enterprises from four regions of the Russian Federation, which carry out innovation activity and are interested in patenting. The majority of respondents are $\mathrm{OOO}(92.5 \%)$ and only $7.5 \%$ are individual entrepreneurs, including $81.7 \%$ of all respondents are representatives of the industrial field of activity. SIE operation period: $19 \%$ of firms - one year; $58 \%$ two years, $21 \%$ three years and the rest more than three years. The data obtained is typical for a small business.

Results of the questionnaire on innovation and patent activities: $53.3 \%$ of SIEs are engaged in the development of 1-2 significant innovations per year and $46.6 \%$ offer radical innovations. These results are predictable, since the concentration of companies on a small number of projects is explained by the limited financial, human and other resources. The results obtained are correlated with general statistical data, according to which $70 \%$ of SIEs patent their developments and $30 \%$ of companies do not.

The main goals of patenting are: improving the company's reputation (92\%), protecting against competition (85\%), participating in competitions for funding $(82 \%)$, increasing the competitiveness of products $(82 \%)$. The reason for patenting, highlighted during the survey, is participation in competitions for funding, presupposes the interaction of the Ministry of Foreign Affairs with the state, and this requires an objective assessment of the quality of the project at an early stage.

In general, $49 \%$ of respondents used the services of patent offices or specialists, namely: conducting a patent search or patent research - 38\% of respondents; taking opinion - 33\%; registration of a license agreement or an alienation agreement - 13\%; registration of application documents for obtaining of patent for an invention or utility model - $10 \%$; development of a patenting strategy - $2 \%$. When choosing a patent office or specialist, ones are guided by the indicators and criteria, presented in Table 5.

Table 5. The results of the customer's assessment of the activity of patent offices

\begin{tabular}{|l|c|}
\hline \multicolumn{1}{|c|}{ Criteria for choosing a patent office } & $\begin{array}{c}\% \\
\text { of } \\
\text { respon } \\
\text { ses }\end{array}$ \\
\hline Service price & 43 \\
\hline Efficiency in the provision of services, including consulting, etc. & 40 \\
\hline Competence of work of patent specialists & 27 \\
\hline The quality of the obtained patent with a high scope of rights & 27 \\
\hline High level of confidence to the patent office & 13
\end{tabular}


Table 5. Continued

\begin{tabular}{|l|c|}
\hline Availability of a patent attorney on the staff & 8 \\
\hline The operating term of the company & 7 \\
\hline Providing a range of services, including the development of a patent strategy & 5 \\
\hline Quality of patent search, provision of statistics on patents & 4 \\
\hline Friendly staff & 3 \\
\hline Convenient office location & 2 \\
\hline Convenient customer service, providing all the requested information & 2 \\
\hline High share of issued patents among filed applications & \\
\cline { 1 - 1 } Economic sustainability of the patent office & \multirow{2}{*}{0} \\
\cline { 1 - 2 } Share of the patent office in the patent services market & \\
\cline { 1 - 2 } Average number of patent applications, filed by one patent specialist & \\
\cline { 1 - 2 } Availability of patent specialists with the necessary specialization in the technical field & \\
\hline
\end{tabular}

As follows from the data presented, the main significant indicators, when choosing a patent organization for the implementation of the required services are: price, efficiency in providing services (including consulting), competence of patent specialists, quality of the obtained patent (for example, with a high scope of rights). The price and efficiency can be determined by the customer quantitatively, and such qualitative characteristics as the competence of specialists and the quality of services are subject to subjective assessment. In order to increase the efficiency of interaction between the SIEs and the patent office, it is necessary to develop criteria for assessing the quality of services and the competence of the patent office employees. This information about patent offices will allow customers to more reasonably approach their contacts.

According to available data, $65 \%$ of SIEs file their patent applications on their own. The reasons for refusing the services of patent offices are given in Table 6.

Table 6. Reasons for refusals from the services of patent offices

\begin{tabular}{|l|c|}
\hline Reasons for refusing to interact with the patent office & $\begin{array}{l}\% \\
\text { responses }\end{array}$ \\
\hline High cost of patent services & 44 \\
\hline The ability to write application documentation by employees of the organization & 33 \\
\hline Lack of assistance in the commercialization of patent development & 29 \\
\hline High competence of the authors of the development & 28 \\
\hline $\begin{array}{l}\text { Lack of a methodology for assessing the quality of the work of a consulting firm, } \\
\text { etc. }\end{array}$ & 9 \\
\hline
\end{tabular}

One of the main reasons for refusal is "lack of assistance in the commercialization of innovation", which indicates the need of small businesses to expand the scope of patent office services and involve government organizations in this work. A survey of clients, who turned to patent specialists for services, showed, that the main argument in favor of a patent office, as opposed to performing this work independently, is to provide them with high-quality services, which are guaranteed by an agreement, signed by the parties. It is not economically feasible to have patent specialists on the staff of the SIE.

Among the responses received (in terms of our research), attention is drawn to the following: the lack of assistance in the commercialization of patent development - $29 \%$ and 
the absence of a methodology for assessing the quality of the work of a consulting firm - $9 \%$. These opinions of representatives of innovative manufacturing firms indicate the importance for them of the full use and introduction of developments.

In connection with the set task to differentiate patents (at the request of customers), it is proposed to assess them on the basis of four components:

- $\quad$ marketing (M): determines the importance of the product, market size, capacity and competitiveness of the product; assessment is carried out by qualified marketing experts;

- $\quad$ technical $(\mathrm{T})$ : determines the inventive step, competitiveness and possibility of application. The technical factor is determined by technical experts;

- $\quad$ innovative (I): assesses the compliance of the development with the priority directions of innovation activity in the region;

- $\quad$ legal (L): assesses the quality of the filed patent application. The legal factor is assessed by patent experts.

That is, the significance of each patent $(\mathrm{E})$ for the region is proposed to be considered as a function of a number of the above variables: $E=f(M, T, I, L)$. The value of each component can be assessed by experts (specialists in their field) on a five-point scale, where 1 is a low mark; 2 - insufficient; 3 - average; 4 - sufficient; 5 - high. As an initial version, the evaluation of the patent $(\mathrm{E})$ in points is proposed to be determined by the formula:

$$
И=\mathrm{K}_{1} * \mathrm{M}+\mathrm{K}_{2} * \mathrm{~T}+\mathrm{K}_{3} * И+\mathrm{K}_{4} * \Pi,
$$

where $\quad \mathrm{K}_{1}, \mathrm{~K}_{2}, \mathrm{~K}_{3}, \mathrm{~K}_{4}$ are the weighting coefficients of the marketing, technical, innovation and legal components of the assessment, respectively.

When processing the data obtained, an assessment of the variation range of expert opinions on the risk module should be carried out, which should not exceed $25 \%$. Based on the results of the assessment of each component, a ranked list of elements and a comprehensive assessment of the patent are made. The developed methodology can be used by many subjects of innovation activity: applicants, investors, government organizations.

\section{Conclusions.}

The developed methodology allows:

- $\quad$ to assess the quality of the patent;

- $\quad$ to increase the commercial potential of developments at the patenting stage;

- $\quad$ to motivate performers to improve the quality of the patent;

- $\quad$ to assess the quality of the work of the patent office;

- $\quad$ to carry out operational examination (in comparison with a detailed analysis of each development);

- $\quad$ to improve the quality of patents.

Thus, the proposed methodology makes it possible to assess the commercial potential of the development at the stage of patenting; improve the information environment, that allows small innovative enterprises and investors to find each other; form standardized criteria for the selection of organizations for state support of innovations; increase the level of use of patent information in the framework of patent activity. This technique is the basic premise for increasing innovation activity in small businesses.

\section{References}

1. F.M. Scherer, D. Ross, The structure of industry markets, 698 (1997)

2. J. Schmookler, Invention and Economic Growth, 332 (1966) 
3. Z. Griliches, Patent statistics as an economic indicator, http://www.nber.org/

4. B. Kh. Hall, Market weight and patent citation, https://eml.berkeley.edu/

5. J-L. Hervas-Oliver, F. Sempere-Ripoll, C. Boronat-Moll, Technological Forecasting and Social Change (2020)

6. J. Sun, V. Maksimov, Y. Luo, Journal of World Business (2020)

7. China's GDP by years: $1980-2019$, http: //global-finances.ru/

8. Y. Wei, S. Miraglia, International Journal of Project Management, 35(4), 571 (2017)

9. S. Yutao, Technological Forecasting and Social Change, 108, 70 (2016)

10. NBS of China. http://www.stats.gov.cn/

11. Number of SMEs in China from 2012 to 2020 (in millions). https://www.statista.com/

12. NBS of China, http://www.stats.gov.cn/

13. World Intellectual Property Organization, http://www.stats.gov.cn/

14. Russian Federal Service for Intellectual Property: figures, facts and projects, Edited by G.P. Ivliev Publishing house of "the Federal State Budgetary Institution Federal Institute of Industrial Property" (FIIP) (2020) https://rupto.ru/

15. V.S Parshina, Z.A. Koreisha, Issues of an innovative economy, 7(1), 31 (2017)

16. S.A. Ilyina, The world of the new economy, 4 (2019)

17. Y. Simachev, M. Kuzyk, V. Feygina, Electronic Journal, 15(2) (2015)

18. M.V. Bedrina, The value of inter-firm interrelations of an industrial enterprise as a source of increasing its competitiveness, http://sun.tsu.ru/

19. N.I. Popov, Marketing approach to assessing the effectiveness of network interfirm relations, 33 (2010)

20. F. P. Hilmersson, M. Hilmersson, Journal of Innovation \& Knowledge (2020)

21. C. Bell, World Patent Information (2000) 